\title{
Effect of Organizational Structure, Job Analysis and Leadership Style to Work Motivation and Its Impact on The Performance of Employees
}

\author{
Andhi Sukma Hanafi ${ }^{1}$, Saiful Bahri ${ }^{2}$, M. Shabri Abd Majid ${ }^{3 *}$
}

${ }^{1)}$ Ministry of Industry, Indonesia; ${ }^{2)}$ Syiah Kuala University, Indonesia

INFORMASI ARTIKEL

\section{Article history:}

Data submission : 19 September 2018

$1^{\text {st }}$ revision: 16 January 2019

Accepted: 19 April 2019

Available online: 02 May 2019

Keywords: Organizational, Job Analysis, Leadership, Motivation, Employees

Performance.

\begin{abstract}
The purpose of this research is to: 1) Influence of organizational structure, job analysis, and leadership style on work motivation, 2) Influence of organizational structure, job analysis, and leadership style on employee performance, 3) Influence of work motivation on employee performance. This study was conducted at SMK SMTI in Indonesia with 183 employees as respondents. This research uses SEM AMOS for data analysis. The study found that organizational structure, job analysis, and leadership style significantly influenced work motivation, while the organizational structure is the highest variable influenced on work motivation with the value of influence of 0,608 . Organizational structure, job analysis, and leadership style significantly influenced the employee performance, while the leadership style variable is the highest variable influence on the performance of employees with the value of influence of 0,946. In addition, work motivation has significantly affected employee performance with an influence value of 0,384 .
\end{abstract}

2019 FIA UB. All rights reserved.

\section{Introduction}

Bureaucracy reform is one of the government's efforts to achieving good governance and reform and fundamental changes to the system of government administration, especially concerning on institutional aspects, management and human resources personnel (employees). The purpose of bureaucratic reform is to create a government bureaucracy that is professional with the characteristics, integrate, high performance, free and clear of corruption, capable of serving the public, neutral, prosperous, dedicated and uphold - basic values and code of ethics of the state apparatus.

Bureucratic reforms conducted at the Ministry of Industry cover nine areas of change, including, change management, controlling, performance accountability, organizational structuring, governance arrangements, structuring human resource management systems, regulatory legislation, public services, and quick wins. Structuring the human resources management system of the apparatus conducted by the Ministry of Industry includes six important elements, including personal information system (SIPEG), planning, internal mutation, development, discipline and code of ethics, and employee performance.

The Ministry of Industry has also implemented bureaucratic reform by forming a bureaucratic reform team of the Ministry of Industry as outlined in Decree of the Minister of Industry number 250/MIND/Kep/3/2016 on the Formation of Bureaucratic Reform Team of the Ministry of Industry. Vocational High School of Technology Industry (SMK SMTI) as an education implementing unit within the Ministry of Industry is also obliged to implement the bureaucratic reform program within the Ministry of Industry. In the arrangement of HR management system apparatus on elements of employee performance, SMK SMTI is 
guided by Regulation of the Minister of Industry Number 98/M-IND/PER/11/2015.

Results SMK SMTI employee jobs reported to the head through an intranet application and assessed through performance appraisal mechanisms by the leadership in accordance with the requirements of the job as agreed in vocational SMTI employee performance targets. However, the possibility of errors made in the assessment. Errors can occur because of the tendency of halo effects, the tendency of centralized assessment, bias too soft and hard, the influence of last impression and personal prejudice. The mechanism of employee performance allowances paid/received by employees every month because of employee performance reporting and assessed by the leadership to give effect to the increase of employee motivation. However, the amount of paid/received performance benefits depends not only on reporting and performance appraisals but also from the grading of SMTI SMK officers.

The existing organizational structure needs to be developed and reviewed because of the growing needs and workload required SMK SMTI. This is in line with the expected results in the reform of bureaucratic reforms, namely the right and proper sizing organization. The Organizational structure has been reviewed influences the grading of SMTI SMK officer position.

Job analysis has been conducted based on the development of organizational structure in each work unit, adjusted to the objectives of the organization, but still constrained on the fulfillment of the number of human resources (HR) on the analysis of positions that have been implemented. The leadership style performed by each leader in SMK SMTI has different characteristics in interacting with employees. The underlying differences in this leadership style, in addition to the characteristics of the leadership, is also influenced by the ability and commitment possessed by SMTI SMK employees in carrying out their work in accordance grading position to fulfill the goals of the organization.

The influence of work motivation on employee performance has been studied by Riyadi (2011), Taghipour (2013), Musliyadi (2015), and Hijri (2016), where the results showed that the increase of work motivation significantly increases employee performance. While the work motivation in this research is influenced by organizational structure variable, job analysis, and leadership style.

The organizational structure has a significant effect on work motivation has been proven in research by Rizka (2015). While the position analysis the performance has been studied by Wulandari (2011). The motivation of work influenced by leadership style has also been significantly examined by Shafi (2015).
However, from various studies above, the research is still done in one area of research object, while this research was conducted in six areas spread throughout Indonesia.

The objectives of this study are to: examine the influence between organizational structure, job analysis, and leadership style on work motivation, examine the influence and significant levels of the organizational structure, job analysis, and leadership style on employee performance, and testing the influence of work motivation on employee performance.

\section{Theory}

\subsection{Employee Performance}

Employee performance is a variable that is influenced by several factors. Factors that affect employee performance according to Mangkunegara (2005) is a factor of ability and motivation. Performance of employees is the work achieved by every employee in the organization unit in accordance with the objectives of employee work and employee productivity (Regulation of the Minister of Industry Number 98/MIND /PER/11/2015). Employee performance was the work achieved an employee based on work plans and targets to be achieved by each employee of the tasks and functions of each employee. Factors that affect employee performance according to Mangkunegara (2005) is an ability factor and motivation. The ability factor consisting of potential ability and knowledge include of skill.

According to the Regulation of the Minister of Industry of the Republic of Indonesia Number 98 / MIND / PER / 11/2015, Employee Performance can be measured by Employee's target and employee work productivity. The employee targets include quantity, quality, time, and cost. While employee productivity includes service orientation, integrity, commitment, discipline, cooperation, and leadership.

\subsection{Work motivation}

Motivation according to Bangun (2012), motivation is defined as an action to influence others to behave on a regular basis. Motivation is a task for the leadership to influence employees in a work agency. From the definition of the above definition of motivation shows that there are three things that include in it, among other efforts, organizational goals and needs. Work motivation is a condition that causes employees to do work to achieve the needs that give satisfaction to employees and affect the achievement of organizational goals. The motivation according to Siswanto (2010) is defined as the psychological state and attitude, the human mental that energizes, encourages activities and leads or channel behavior toward achieving needs that satisfy or reduce imbalances. 
According Sutrisno (2010) factors that affect work motivation consists of internal factors and external factors. While according Saydan in Rizka (2015), that are indicators of a person's motivate work consists of increasing the quality of jobs, tasks according to ability, high employment initiatives, working relationships between managers and employees, the sacrifice of employees.

\subsection{Organizational structure}

According to Robbins and Coulter (2010), an organizational structure is a formal job arrangement within an organization, where work is divided formally, grouped and coordinated. The organizational structure can be defined as a formal organizational framework within which framework work tasks are divided, grouped and coordinated (Robbins, 2008). The organizational structure of SMK SMTI has been standardized in the Regulations Minister Industry Number 77/M-IND/PER/08/2011 concerning Organization and Work Procedures SMK SMTI. An Indicator of the organizational structure according to Robbins (2008), is a specialization of work, departmentalization, a chain of a span command, control, centralization, decentralization, and formalization.

\subsection{Job Analysis}

A position analysis is a form of development of a detailed description of the tasks to be performed in a position, the determination of the relationship of a position to another position, and the determination of the knowledge, skills and other capabilities required by the employee to perform the work effectively and efficient (Robbins, 2008). Further, Sofyandi (2008) describes the definition of job analysis as a systematic process to find out about the content of a jobwhich includes tasks, tasks, responsibilities, authority and working conditions, and on terms qualifications required such as education, skills, abilities, work experience and others, so that someone can perform tasks in a position well .

Moekijat (2005) stated procedures include job analysis, planning, job analysis, selection of positionspositions that will be analyzed, what is analyzed, the type of information collected job title, source-resources information office, the people who are responsible for the collection of job analysis information, job analysis method, and who is responsible for the position being analyzed.

Position analysis is something that needs to be done by the organization as a basis for determining the right human resources strategy in the face of organizational development more dynamic. The indicators for job analysis are the authority, responsibilities, working conditions, work facilities, standards of work, education, training, and competence (Robbins, 2008).

\subsection{Leadership Style}

According Bangun (2012) style of leadership is a process to direct and influence others in order to perform their duties to achieve organizational goals. According to Hasibuan (2007), there are several types of leadership such as authoritarian leadership style, democratic and free control. The style of leadership is a way that leaders use in interacting with their subordinates (Tjiptono, 2006).

Authoritarian leadership is that if power or authority is largely absolute remains in the leadership or if the leadership embraces a centralized system of authority. The democratic leadership is the leadership exercised by persuasive means, creating a harmonious cooperation, foster loyalty, and participation followers. As for the leadership of free control is the leader delegate authority to subordinates with somewhat complete.

Leadership style indicator according to Hasibuan (2007) as follows: authoritarian leadership, indicated by threat, tight control, and closed system; democratic leadership indicated by communication, consultative, and open system, and free control leadership, indicated by tilings of skill, trust, and freedom.

\subsection{Influence of Variables}

Motivation according to Bangun (2012), motivation is defined as an action to influence others to behave on a regular basis. Furthermore, Taghipour (2013) states that work motivation is related to employee performance, whereby when employees are motivated to enter the workplace, performance will increase. In addition, the working relationship between leaders as a motivator can improve the performance of employees in the organization.

According to Ardana (2008), there are two factors that affect the motivation of intrinsic motivation and extrinsic motivation. Intrinsic motivation is a motivation derived from stimuli within the company. In general, individual characteristics also affect how people judge what it gained from stimuli in the company. Extrinsic motivation is manifested in the form of external stimuli aimed at moving individuals to perform an activity that brings benefits to the individual itself. This extrinsic motivation can be stimulated in forms such as salary, work environment, interpersonal relationships, company policies or regulations, leadership or supervision. The purpose is more realistic the existence of the organizational structure design that can affect the motivation and commitment of members to achieve organizational goals (Philip, 2000). The design of an organization has important implications for the firm's competitive advantage in which one is to improve the coordination and motivation of the workers (Vishnu, 2005).

In a study conducted by Wulandari (2011) on the influence of job analysis on employee work motivation 
of Faculty of Engineering, Trunojoyo Madura University, correlation coefficient and determinant coefficient shows that this method is very effective because it consists of five indicators on job analysis, position of a position, a position, duty, authority, and responsibility. While the work motivation consists of achievement, recognition/ award, career development, salary/wages, absenteeism. This means that the position analysis is done by the Faculty of Engineering, Trunojoyo Madura University so that employees will be motivated by the increase of work motivation.

A good leadership style is a leadership style that can provide motivation to work on subordinates. Ivancevich (2001) says a leader must integrate skills, experience, personality, and motivation. Employee performance will be good if the leader can provide the right motivation and leadership has a leadership style that can be accepted by all employees and support the creation of a good working atmosphere.

Based on the explanation above, the hyphotesis proposed in this study is structure organization, job analysis, and leadership style affect the employee's motivation to work $\left(\mathrm{H}_{1}\right)$; Organizational structure, job analysis, and leadership style affect the performance of employees $\left(\mathrm{H}_{2}\right)$ and Work motivation affect the performance of employees $\left(\mathrm{H}_{3}\right)$.

\section{Research Methods}

This research is a type of hypothesis testing research on the influence of organizational structure, job analysis and leadership style on work motivation and its impact on employee performance. The location of the research is SMK SMTI in Indonesia.

The population according to Sujarweni (2012) is defined as a generalization region consisting of objects or subjects that have certain qualities and characteristics set by the researcher to be studied and then drawn conclusions. The Population of this research is all employees at SMK SMTI in Indonesia amounted to 339 employees.

The sample is part of the number and characteristics possessed by the population (Sugiyono, 2013). Technique in research this use Probability Sampling with method Cluster Sampling. Probability sampling is technique taking samples giving equal opportunity for every element (members) of the population for selected be member sample (Sugiyono, 2013). The researchers determined the minimum number of samples with slovin calculations, then the number of samples in this study was 183 Employees (Sanusi, 2011).

Analysis and interpretation of data for research aimed to answer the question of research to reveal certain social phenomena. This research uses Structural Equation Modeling (SEM) method with the help of AMOS program. Stages of modeling and analysis of structural equations according to Ghozali (2014) are divided into seven steps: theory-based modeling, path diagramming, transforming path diagrams into structural equations, selecting input matrices for data analysis, assessing model identification, evaluating estimates model, and interpretation of the model. This research model can be seen in Figure 1.

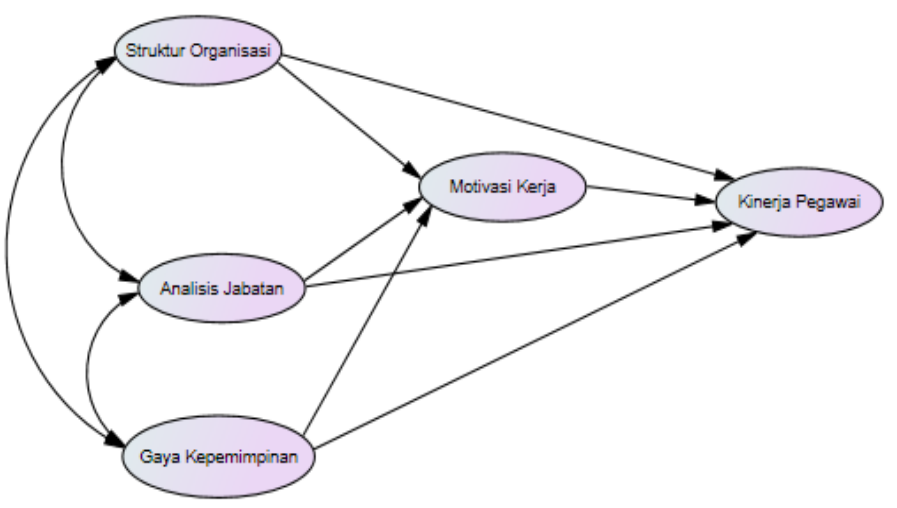

Figure 1. Research model

\section{Results}

Test validity with validity convergent test, ie test construct (indicator) whether having high variance proportion or not. The criteria that must be met is the loading factor standardized loading estimate $>0,500$. The results obtained in this study indicate the Loading Factor above 0,500 then said that the indicator is representative enough to explain the unobserved variable in figure 2.

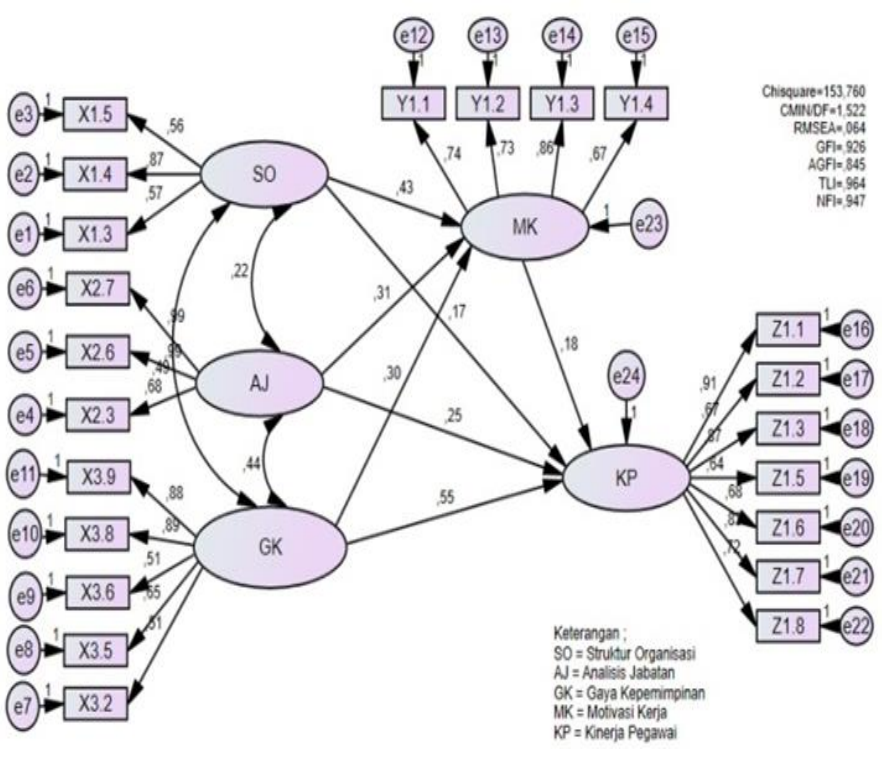

Figure 2. Results of SEM

Reliability is a measure of the internal consistency of the indicators of a construct showing the degree to which each indicates a common latent construct/factor. In other words how are specific things help each other in explaining a common phenomenon. Reliability test with 
Construct Reliability (CR) test, which is to test the reliability and consistency of data. The criteria for CR > 0.700 .

Test data normality with normality of Univariate and Multivariate, to analyze level data normality used in this research. Univariate view CR value on Skewness is expected around $+2,58$. From this research can be seen that the value of minimum skewness $\mathrm{CR}$ is ranged between +2.58 , with a maximum value of 2,409 . Thus, it can be said that the data in this study there is no outlier data.

Generally, using the goodness of fit test, it can be concluded that the existing model meets the fit criteria. So that the output is out of this model must be a finding or findings of the study related to the relationship between the indicator with each construct. Table 1 describes the results of the Goodness of Fit evaluation.

There is influence between the variable independent organizational structure of the variable dependent work motivation. The significant level relationship between of the organizational structure with work motivation worth 0,609 . The results of this study consistent with research conducted by Rizka (2015), where the results showed that the organizational structure has a significant effect on work motivation. The significant level of relationship between job analysis on work motivation worth 0,332 . The results of this study are consistent with the research conducted by Wulandari (2011) and Rizka (2015), where the results showed that job analysis has a significant effect on work motivation. The signiificant level of leadership style to the dependent variable of work motivation, there is a significant influence of 0 , 241. The results of this study are consistent with the research conducted by Riyadi (2011), Syafi'i (2015) and Hijri (2016), where the results showed that leadership style had a significant effect on work motivation.

Table 1. Goodness of fit

\begin{tabular}{llccc}
\hline No & Criteria & Cut Off Value & Result & Mark \\
\hline 1 & Chi-Square & Small much better & 143,366 & Fit \\
2 & RMSEA & $<0,08$ & 0,064 & Fit \\
3 & GFI & $>0,90$ & 0,926 & Fit \\
4 & CMIN/DF & $<2,00$ & 1,748 & Fit \\
5 & TLI & $>0,90$ & 0,965 & Fit \\
6 & CFI & $>0,90$ & 0,981 & Fit \\
\hline
\end{tabular}

From the results of the above analysis, the organizational variable is the variable that has the highest influence on work motivation with the value of the influence of 0,609 .

There is influence between independent variable of organizational structure to the employee performance. The significant level of relationship between organizational structure on employee performance worth 0,513 . The results of this study are consistent with the research conducted by Ogbonna (2003), Budiasih (2012), and Jacob Setiawan (2016), where the results show that the organizational structure has a significant effect on employee performance. The significant level of job analysis on work motivation worth 0,568 . The results of this study are consistent with the research conducted Fathimatuzzuhroh (2011) and Tanumihardjo (2013), where the results showed that the analysis of positions have a significant effect on employee performance. The significant level of leadership style to variable dependent employee performance worth 0,946 . The results of this study are consistent with research conducted by Somech (2006), Riyadi (2011), Sulaiman (2013), Syafi'i (2015), Setiawan (2016) and Hijri (2016), where the results show that leadership style has significant influence on employee performance.

From the results of the above analysis, the leadership style variable is the variable that has the highest influence on the performance of employees with the value of influence of 0,946 .

There is influence between the dependent variable of work motivation to the dependent variable of employee performance. The significant level of relationship between organizational structure on employee performance worth 0,384 (any improvement in work motivation will lead to improved employee performance). The result of this research is consistent with research conducted by Riyadi (2011), Taghipour (2013), Musliyadi (2015), and Hijri (2016) where the result of research indicates that work motivation has significant effect to employee performance.

\section{Discussion and conclusion}

Based on research results and conclusions of research is expected to provide benefits to some parties, in this case, the Head of SMK SMTI to improve the performance of employees, through the motivation of work, organizational structure, job analysis and leadership style.

Given this research is expected to Head of SMK SMTI in Indonesia as a unit leader who is responsible to the Head of the Industrial Training Center of the Ministry of Industry, to realize that leadership style is very influential on the performance of employees in vocational SMTI. So that each Head of SMK SMTI can adjust his style of leadership in accordance with the conditions of each area. The leadership style that is very influential in improving the performance of employees is the type of leadership style free so that the Head of SMK SMTI in Indonesia can do that the leadership style appropriate to the type of leadership style indicators free rein. In the style of leadership type of free rein, is expected to Head of SMK SMTI still providing the confidence and authority to staff to carry out and complete the work in accordance with the ability of each employee, without leaving the monitoring and 
evaluation of the completion of the work, and provide consultation as required in settlement work.

Based on the results of research and discussion that has been described, it can be concluded for research that aims to determine the effect of variable organizational structure, job analysis, leadership style, the work motivation and its impact on employee performance is divided into four sub models. The first sub model is to look at the effect of the organizational structure, job analysis, and leadership style on job motivation, the second sub model to see the effect of the organizational structure, job analysis, and leadership style of the performance of an employee, and the third sub model see the effect of work motivation on employee performance.

In the first sub model it can be concluded that there is significant influence and positive between the organizational structure, job analysis, and leadership style on job motivation, means the better the organizational structure, the better the job analysis, and the better style of leadership, the higher the motivation of employee SMK SMTI in Indonesia. The highest variable affecting motivation to work is the organizational structure, this will prove the role of the organizational structure is an important factor to increase employee motivation.

Conclusion for the second sub model is the organizational structure, job analysis, and leadership style influence significantly and positively on the performance of an employee, means the better the organizational structure, the better the job analysis, and the better your leadership style than the higher the employee's performance SMK SMTI in Indonesia. Leadership style variable also has the highest influence on employee performance, demonstrating the role of Head of SMK SMTI as leadership is an important factor in improving employee performance.

Conclusion The third sub model is the work motivation and positive significant influence on employee performance, meaning that the higher work motivation than the higher the employee's performance SMK SMTI in Indonesia. Employee motivation can be shown on the willingness of employees to carry out their work SMK SMTI professionally, effectively and efficiently. This is what will affect the performance of employees in Indonesia SMK SMTI.

\section{References}

Ardana, K. (2008), Perilaku Keorganisasian. Yogyakarta: Graha Ilmu.

Bangun,W. (2012). Manajemen Sumber Daya Manusia. Jakarta : PT. Gelora Penerbit Erlangga.

Ghozali, I. (2014). Model Persamaan Struktural: Konsep dan Aplikasi dengan Program AMOS 22.0Update Bayesian SEM. Semarang: Badan Penerbit Universitas Diponegoro.
Hasibuan,M.S.P. (2007), Manajemen SDM. Edisi Revisi. Jakarta:PT.Bumi Aksara.

Hijri, S. (2016), Pengaruh gaya kepemimpinan dan motivasi terhadap motivasi kerja serta dampaknya pada kinerja pegawai Badan Pelaksana Penyuluhan Pertanian, Perikanan dan Kehutanan (BP4K) Kabupaten Aceh Barat. Banda Aceh: Universitas Syiah Kuala.

Ivancevich. (2008), Perilaku dan Manajemen Organisasi. Jakarta : Erlangga.

Keputusan Menteri Perindustrian Nomor 250/MIND/Kep/3/2016 tentang Tim Reformasi Birokrasi Kementerian Perindustrian.

Mangkunegara, A.P.(2005). Manajemen Sumber Daya Manusia Perusahaan. Bandung: PT. Remaja Rosdakarya.

Musliyadi. (2015), Pengaruh insentif, motivasi, lingkungan kerja dan budaya organisasi terhadap kinerja pegawai serta dampaknya pada kinerja badan layanan umum daerah rumah sakit umum Thk. Chik Ditiro Sigli Aceh. Banda Aceh: Universitas Syiah Kuala

Moekijat. (2005). Manajemen Kepegawaian. Bandung: Alumni.

Peraturan Menteri Perindustrian Nomor 77/MIND/PER/08/2011 tentang Organisasi dan Tata Kerja Sekolah Menengah Kejuruan - SMTI.

Peraturan Menteri Perindustrian Nomor 98/MIND/PER/11/2015 tentang Mekanisme Pemberian Tunjangan Kinerja Bagi Pegawai di Lingkungan Kementerian Perindustrian.

Philip, S. (2000), Mendesain Organisasi. Jakarta: Pustaka Binaman Pressindo.

Rizka, N. Yusuf, R. Majid, M.S.A. (2015). Pengaruh struktur organisasi dan analisis jabatan terhadap motivasi kerja dan dampaknya pada kinerja sekretariat Majelis Permusyawaran Ulama (MPU) Aceh. Jurnal Manajemen Pascasarjana Universitas Syiah Kuala, 2(2), 1-9.

Riyadi, S. (2011), Pengaruh kompensasi finansial, gaya kepemimpinan dan motivasi kerja terhadap kinerja karyawan pada perusahaan manufaktur di jawa timur. Jurnal Manajemen dan Kewirausahaan, 13(1), 2011, 40-45.

Rizka, N., Yusuf, R. Majid, M.S.A. (2015), Pengaruh struktur organisasi dan analisis jabatan terhadap motivasi kerja dan dampaknya pada kinerja sekretariat Majelis Permusyawaran Ulama (MPU) Aceh. Jurnal Manajemen Pascasarjana Universitas Syiah Kuala, 2(3), 1-9.

Robbins, S., dan Timothy A. J. (2008). Perilaku Organisasi, Organizational Behaviour. Buku Terjemahan. Jakarta: Gramedia

Robbins,S. P. \& Coulter,M. (2010). Manajemen, Edisi Ke 10, jilid 1. Jakarta: Erlangga. 
Sanusi, A. (2011). Metode Penelitian Bisnis. Jakarta: Salemba Empat.

Siswanto, H.B. (2010). Pengantar Manajemen. Bandung: Bumi Aksara.

Sofyandi, H. (2008). Manajemen Sumber Daya Manusia. Edisi Pertama. Yogyakarta: Graha Ilmu.

Sugiyono, (2013). Metode Penelitian Pendidikan (Pendekatan Kuantitatif dan Kualitatif, dan $R \& D)$. Bandung: Alfabeta.

Sujarweni, V. W. Endrayanto, P. (2012). Statistika Untuk Penelitian. Yogyakarta: Graha Ilmu.

Sutrisno, E. (2010). Manajemen Sumber Daya Manusia. Edisi 1. Cetakan Kedua. Jakarta : Prenada Media Group.

Syafii, L. I. Thoyib, A. Nimran, U. Djumahir (2015), The Role of Corporate Culture and Employee Motivation as a Mediating Variable of Leadership Style related with the Employee Performance (Studies in Perum Perhutani). Procedia - Social and Behavioral Sciences, 211(1), 1142 - 1147.

Taghipour, A. dan Dejban, R (2013), Job Performance: Mediate Mechanism of Work Motivation. Procedia Social Behavioral Sciences, 84(3), 1601 - 1605.

Tjiptono, F. (2006). Manajemen Pelayanan Jasa. Yogyakarta : Penerbit Andi.

Wisnu, D. , Nurhasanah, S. (2005), Teori Organisasi, Struktur dan Desain. Malang: UMM Press. 